\title{
Non-structural Carbohydrates in Dormant Woody Perennials; The Tale of Winter Survival and Spring Arrival
}

\author{
Aude Tixier ${ }^{1 *}$, Gregory A. Gambetta ${ }^{2}$, Jessie Godfrey ${ }^{3}$, Jessica Orozco ${ }^{3}$ and \\ Maciej A. Zwieniecki ${ }^{3}$ \\ ${ }^{1}$ UMR 1347 Agroécologie, AgroSup/INRA/uB, Dijon, France, ${ }^{2}$ UMR EGFV, Bordeaux Sciences Agro, INRA, Université de \\ Bordeaux, Bordeaux, France, ${ }^{3}$ Department of Plant Sciences, University of California, Davis, Davis, CA, United States
}

\section{OPEN ACCESS}

Edited by:

Sanna Sevanto,

Los Alamos National Laboratory

(DOE), United States

Reviewed by:

Eric J. Ward

United States Geological Survey,

United States

Sheel Bansal,

United States Geological Survey,

United States

Anna Monrad Jensen,

Linnaeus University, Sweden

*Correspondence:

Aude Tixier

aude.tixier@inra.fr

Specialty section

This article was submitted to

Forest Ecophysiology,

a section of the journa

Frontiers in Forests and Global

Change

Received: 01 March 2019

Accepted: 23 April 2019

Published: 08 May 2019

Citation:

Tixier A, Gambetta GA, Godfrey J, Orozco J and Zwieniecki MA (2019)

Non-structural Carbohydrates in

Dormant Woody Perennials; The Tale

of Winter Survival and Spring Arrival.

Front. For. Glob. Change 2:18.

doi: 10.3389/ffgc.2019.00018
Woody perennials' reliance on nonstructural carbohydrates (NSC) reserves for the resumption of spring growth necessitates an accumulation of NSC prior to dormancy. It is assumed that during dormancy temperature-regulated biological activities gauge the progression of winter and affect the metabolic rates and physiology of NSC reserves. Thus, changes in temperature signal the arrival of spring and determine the amount of reserves available for growth resumption. As woody perennials are dependent on dispersed storage of NSC during spring, they need an integrated remobilization and redistribution for synchronous and effective development of photosynthetic and reproductive organs. However, it is not known how storage compartments interact at the whole plant level, when NSC reserves are mobilized, or how local and distal storage compartments influence the biology of spring growth resumption. The goal of this mini-review is to shift the focus of winter biology from bud-centric to the whole plant. We discuss winter NSC management in the context of climate change with a special emphasis on how projected mild winters may affect the carbon budget, transport, and allocation during winter. We look at three aspects of NSC regulation underlying dormancy (I) the molecular regulation of dormancy (II) temperature dependent winter NSC metabolism, and (III) spring NSC remobilization and redistribution processes.

Keywords: NSC, bud break, chilling models, starch, sugars, xylem

\section{INTRODUCTION}

The perennial habit in mediterranean, boreal, and temperate climates necessitates overwintering. In order to ensure their survival during this harsh time, species have evolved adaptive phenological mechanisms that modulate annual growth, and induce dormancy cycles and cold acclimation. During fall, woody perennials (trees and vines) respond to the decreasing temperature and photoperiod by halting growth, accumulating non-structural carbohydrates (NSC, i.e., sugars and starch), shedding leaves, and acquiring cold hardiness (Charrier et al., 2015). While the arrival of spring is linked to day length, temperature is the principal environmental regulator signaling the progression of dormancy from winter (accumulation of "chill") into spring (accumulation of "heat"), resulting in the timely end of dormancy and synchronous resumption of growth (Campoy et al., 2011; Sánchez-Pérez et al., 2014). However, the biological mechanisms driving this regulation are not well-understood, partly because temperature affects the physiology of plants both directly, through its effect on enzymatic activities and biochemical reactions, and indirectly through 
multiple signaling pathways (Heide, 2008, 2011; Wigge, 2013). This lack of knowledge results in a guessing game, supported only by statistical models, to assess the impacts of future climate change on perennial ecosystems and agriculture. A mechanistic understanding of dormancy is a prerequisite for sustainably managing forests and agrosystems into the climatic "new normal."

Temperature heavily influences the timing and quality of bud break (Alves et al., 2007; Bonhomme et al., 2010). As winter temperatures are affected by climate change, models predict that in the upcoming decades mediterranean and temperate regions will experience increases in average winter temperatures and an increase in diurnal temperature variations (Luedeling et al., 2013; Field et al., 2014). In general, warmer winters will result in the reduction of chilling hours leading to phenology shifts and eventually to erratic phenology patterns, including the loss of synchronization in bud break at both the individual plant and population level (Pérez et al., 2008; Sanz-Pérez et al., 2009). The negative impacts of warmer winters are already visible in both natural ecosystems and agriculture, apparent in phenological shifts and reduced crop yields (Cleland et al., 2007; Ford et al., 2016; Mosedale et al., 2016). Because we lack an in-depth understanding of the physiological and genetic basis of dormancy and bud break, our ability to leverage a critical target to mediate future climate change is limited.

For the past 20 years the genetic basis of dormancy has been a focus of applied and basic research, with the underlying assumption that the buds are the primary temperature sensors (Rohde and Bhalerao, 2007; Ruttink et al., 2007; Tarkowski and Van den Ende, 2015). These studies highlighted the importance of carbohydrate metabolism, without providing any mechanistic link between temperature and phenology (Mathiason et al., 2009; Fennell et al., 2015; Kim et al., 2017; Singh et al., 2017). These findings need to be complemented with a holistic approach in understating the synchrony of dormancy breaking which takes into account the whole plant sustaining new bud growth. Indeed, buds require energy (in the form of NSC) for biomass, metabolism, and respiration until they transition from heterotrophy (reserve-dependent growth) to autotrophy (photosynthetic autonomy) (Blanke and Leyhe, 1989; Leyhe and Blanke, 1989; Maurel et al., 2004; Vaillant-Gaveau et al., 2011; Tixier et al., 2017b). Bud development, its synchronization at the plant and population levels, and subsequent reproductive success are dependent on the whole plant's ability to supply buds with energy and water (Lebon et al., 2008; Keller and Tarara, 2010). In order to provide this needed energy, NSC are stored in parenchyma cells of wood and roots before winter, ensuring survival, and later remobilized to support bud-break and growth resumption in the spring (Figure 1) (Loescher et al., 1990; Barbaroux and Bréda, 2002; Richardson et al., 2013; Rosas et al., 2013). This dormancy period is inadequately understood at the mechanistic level which limits our ability to build robust phenology models and understand the role of NSC in the resilience of perennials to stresses, especially at limits of species range (Bansal and Germino, 2008, 2010).

Current mechanistic models were developed from the perspective of carbohydrate partitioning and source-sink relationships during the growing season (DeJong et al., 2011; Da Silva et al., 2014). In these models winter biology is usually represented as maintenance respiration, an oversimplification that ignores an entire suite of biological activities related to winter temperature, winter carbohydrate management, transport, and subsequent spring performance (Lacointe et al., 2004; Bonhomme et al., 2005; Pellegrino et al., 2014; Tixier et al., 2017b). On the other hand, models that focus on dormancy such as the chilling hours models (Utah chill models, dynamic model), which were developed to predict bud break in response to winter temperature, are descriptive and empirical in nature (Pérez et al., 2008; Aslamarz et al., 2010; Luedeling and Brown, 2011; Luedeling et al., 2013; Londo and Johnson, 2014). They routinely require continuous recalibrations for new locations, years, species, or genotypes (Guo et al., 2015; Kaufmann and Blanke, 2017). In light of these observations, we argue for the need to develop new mechanistically based models that integrate a whole plant analysis of winter biology and dormancy breaking.

The goal of this review is to concisely present our current knowledge on the role of carbohydrate metabolism and redistribution during winter and spring growth resumption in woody perennials. We will present the molecular basis of dormancy, the temperature-dependent winter NSC metabolism, and finally discuss the mechanisms controlling NSC remobilization and redistribution in the spring. We aim to identify knowledge gaps that should be addressed in the future to inform robust predictive models and establish a holistic understanding of winter biology.

\section{Molecular Basis of Whole-Plant Winter Dormancy}

Dormancy induction and spring growth resumption are coordinated by many molecular pathways. Recent transcriptomic approaches focusing on buds have highlighted the importance of major gene ontology groups including carbohydrate metabolism, stress response, reactive oxygen species (ROS) metabolism, hormonal signaling, MADS-box genes known as DORMANCYASSOCIATED MADS (DAM), and circadian clock regulators for the regulation of dormancy's progress. Highly conserved in eukaryotic organisms, MADS-box genes encode transcription factors are known to participate in the regulation of the plant transition to flower and fruit development (Amasino, 2010). In peach, the deletion of a cluster of six DAM genes has led to a non-dormant phenotype (Rodriguez et al., 1994; Maurya and Bhalerao, 2017). In grapevine buds, dormancy phases such as initiation and bud break coincided with successive expression of DAM genes (Mathiason et al., 2009; Díaz-Riquelme et al., 2012; Fennell et al., 2015). Recently, another regulator gene, EARLY $B U D-B R E A K 1$ (EBB1), encoding a putative ethylene responsive transcription factor has been shown to modulate the timing of bud-break (Yordanov et al., 2014). Other hormones, such as abscissic acid and gibberellins, are also involved in dormancy regulation (Zheng et al., 2015; Maurya and Bhalerao, 2017). There is consensus that these pathways have complex interactions that are unique to each species despite sharing common regulatory components with herbaceous floral transition. However, no 


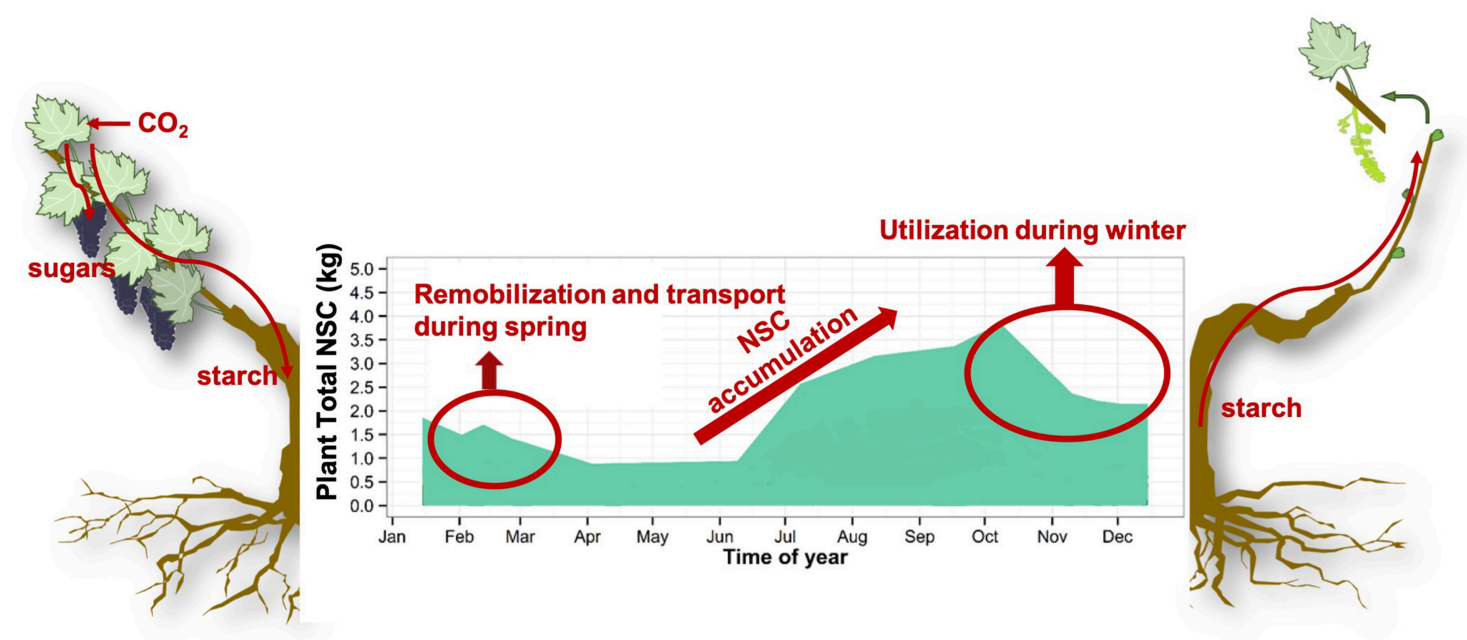

FIGURE 1 | Non-structural carbohydrates (NSC) are stored in the form of starch during the growing season in order to be mobilized to ensure winter survival and development of new organs and tissue during spring. Atmospheric carbon is fixed by photosynthesis in the form of sugar and stored in the form of starch in parenchyma cells of wood and roots. During winter, NSC (sugar and starch) are utilized to ensure survival via maintenance respiration, ROS scavenging, frost resistance, embolism refilling and membrane stabilization. During spring, stored NSC are remobilized as building blocks for the development and growth of new organs and tissues. Plant total NSC is modeled from NSC concentration experimental data and modeled biomass.

regulatory mechanisms underpinning dormancy progression have been identified so far and there is no clear evidence to date on how the environment triggers their activity.

Photoperiodic regulation of dormancy could involve phytochromes (PHY) and the circadian clock (SOC/FT genes) since over-expression of a PHYA prevents short (SD)photoperiod endodormancy in poplar (Bohlenius et al., 2006). Circadian variations are intimately linked with temperature fluctuations and the molecular circadian clock has been shown to be altered by low temperatures in winter perhaps through the recently identified thermo-sensor function of phytochromes (Ruttink et al., 2007; Ibañez et al., 2008; Jae-Hoon et al., 2016; Legris et al., 2016). While phytochromes may provide real-time temperature sensing the remaining problem is identifying the clock that measures the cumulation of "chill hours" during winter progression. This puzzling aspect of dormancy might be related to intrinsic links between the molecular clock and carbohydrate metabolism. There is mounting evidence that local NSC balance is controlled on a diurnal basis, crucial for dormancy breaking, and recent reports even suggests that the clock is actually entrained by sugar signaling (Gibon et al., 2004; Bolouri Moghaddam and Van den Ende, 2013; Palacio et al., 2014; Tixier et al., 2018). If true, sugar homeostasis and starchdegradation enzymatic equilibrium might be at the forefront of dormancy sensing. Indeed, starch degradation-synthesis enzymatic equilibrium maintains sugars homeostasis in living cells and responds to temperature. This response relies on the higher sensitivity to the temperature of starch synthesis than degradation (thermal coefficient of $\mathrm{Q}_{10} 3$ and 1.8-2.5, respectively), thus typically degradation rates are higher than synthesis rates at low temperatures (Zwieniecki et al., 2015). The proposed mode of action of chill substitute chemicals such as hydrogen cyanamide is also consistent with a role of sugar homeostasis in the breaking of dormancy. Hydrogen cyanamide induces ROS production leading to an energetic crisis at the cell level, inducing the expression of amylolytic enzymes, and promoting starch degradation and sugar accumulation in vicinity of the buds (Sudawan et al., 2016).

Unfortunately almost all genetic analysis of dormancy control is focused on buds, while the rest of the plant, which must change simultaneously to provide developing tissue with energy, water, and nutrients, is significantly understudied. For example, only a handful of studies look at the expression of genes in dormant wood. At the xylem level, dormancy coincides with the upregulation of the expression of carbohydrate metabolic genes and acclimation to cold temperature related CBF (C-repeat binding factor) transcription factors while down-regulating cell cycling genes (Schrader et al., 2004; Decourteix et al., 2008; Barros et al., 2012; Tarkowski and Van den Ende, 2015). Considering the trophic relationship between buds and wood, and that rootstocks have been shown to influence the dates of bud break, it is important to identify which organ(s) signals the breaking of dormancy to the rest of the plant and to understand to what extent each organ is autonomous in this process (Menora et al., 2015). Callose deposition in plasmodesmata to isolate buds' symplast at the initiation of dormancy has been hypothesized to limit the access of growth promoting signals but thus far genetic evidence to support this hypothesis has been lacking (Rinne et al., 1994; van der Schoot and Rinne, 2011). The analysis of the molecular dialogue between buds and storage sites (stems and root) during dormancy and dormancy breaking, and gene expression patterns at the whole plant level, would be important milestones for the mechanistic understanding of dormancy. 


\section{Effects of Temperature on Winter and Spring NSC Management}

In addition to its critical role in the breaking of dormancy and the development of buds, local NSC management is also crucial for winter survival, ensuring baseline metabolism through maintenance respiration, frost tolerance, xylem refilling, ROS scavenging, membrane stabilization, and signaling (Bonhomme et al., 2005; Rohde and Bhalerao, 2007; Lebon et al., 2008; Charrier et al., 2015; Tarkowski and Van den Ende, 2015). During winter, respiration converts stored NSC into energy. While respiration increases exponentially with temperature according to the Arrhenius law, its rate and slope decreases with the buds' depth of dormancy (Parada et al., 2016). Whether a similar respiration acclimation response during dormancy exists in other perennial organs, especially the roots, is still an open question that has implications for local NSC consumption (van der Schoot and Rinne, 2011; Keller, 2015). Respiration displays thermal acclimation and recent observations even showed stem respiration increases in response to near freezing temperatures in pistachio and oak trees (Atkin and Tjoelker, 2003; Sperling et al., 2015). Thus, characterizing accurate respiration responses to temperature is a major challenge for mechanistic models that generally assume a simple exponential function with a constant $\mathrm{Q}_{10}$ of near 2 .

In response to low and freezing temperatures, stored starch is converted to soluble sugars or other compatible solutes to decrease cell osmotic potential (Bonhomme et al., 2005; Zwieniecki et al., 2015). Combined with the dehydration of cells, decreased osmotic potential lowers the freezing point of living cells preventing ice damage. Compatible solutes such as sugars can stabilize membranes and macromolecules, and also scavenge ROS (Tarkowski and Van den Ende, 2015; Beauvieux et al., 2018). The increase of starch degradation rate in response to low temperature can be related not only to changes in metabolic gene expression but also enzyme activity (Witt and Sauter, 1994). Indeed, a cell's sugars homeostasis is maintained by the degradation-synthesis enzymatic equilibrium and the exchange with the apoplast which has a major role in xylem for transport capacity (Zwieniecki et al., 2015). The export of sugars to the xylem apoplast lowers its osmotic potential and protects it against freezing. If xylem sap does freeze, insoluble gas bubbles may form and expand in vessels when thawing (Améglio et al., 2002, 2004). Gas-filled-vessels or embolized vessels can no longer transport water (Lens et al., 2012). During thawing, sugar export into the xylem apoplast may help dissolve embolisms formed during freeze-thaw cycles thus ensuring an intact water transport pathway for spring.

Milder winters and increased frequency of freeze thaw cycles predicted by climate change models might accelerate the drawdown of NSC reserves and the resulting drop in the spring carbon budget might negatively affect growth resumption during spring (Sperling et al., 2015; Charrier et al., 2018). In grapes, increasing bud temperature induces persistent season-long changes in shoot development in terms of phenology, growth, and whole plant carbon budget (Keller and Tarara, 2010). Even small changes in the temperature of branches can have an effect on their spatial distribution of carbohydrates contents and their phenology

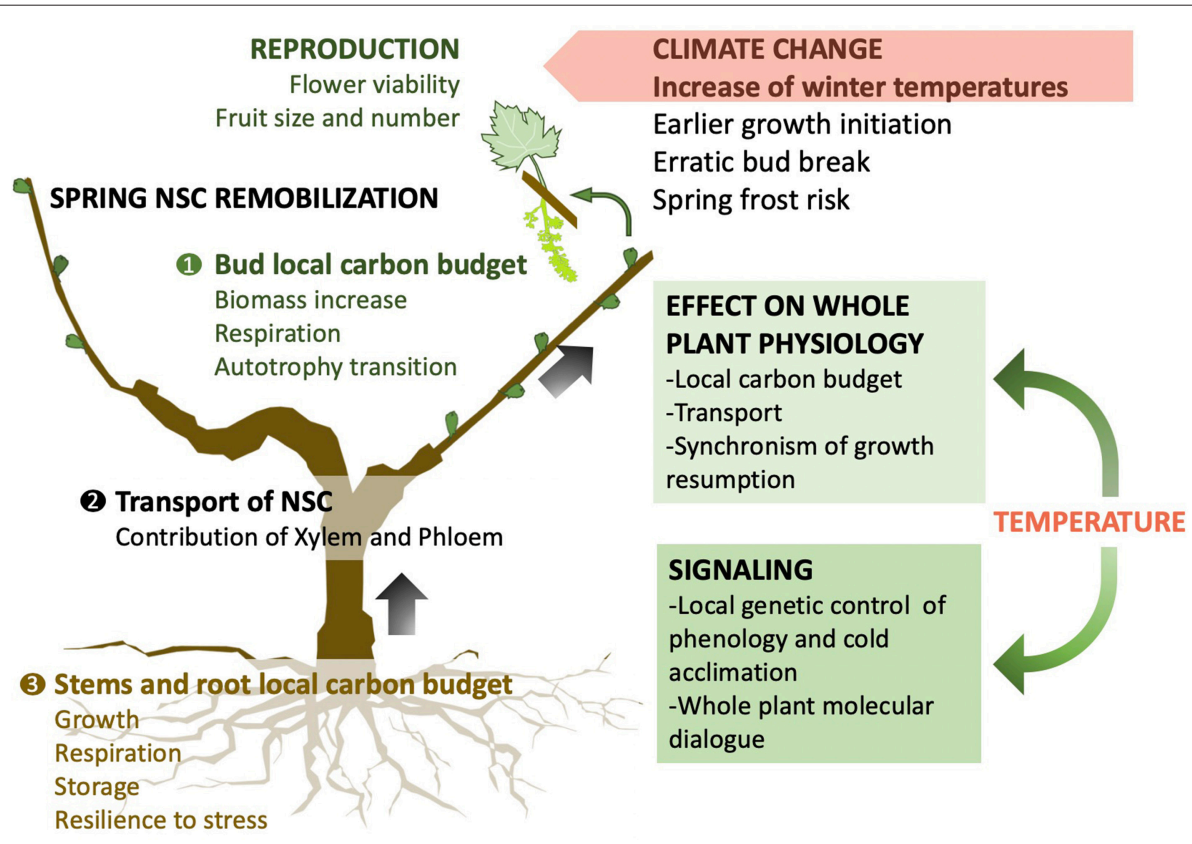

FIGURE 2 | Conceptual graph of holistic framework to study non-structural carbohydrate (NSC) implication in winter biology and spring growth resumption within the context of climate change. Temperature has a local signaling and physiological effect on each organ of perennial plants which will affect the local carbon budget. The integration of transport mechanisms is crucial to unravel the suite of biological activities that leads to budbreak and successful growth resumption at the whole plant level. 
in walnut (Tixier et al., 2017a). The resumption of growth and the organogenesis of new photosynthetic organs require mobilization of NSC as building blocks for these new tissues (Bonhomme et al., 2010; Hartmann and Trumbore, 2016). It is not known how the main storage compartments (i.e., wood and roots) of NSC interact, what triggers the mobilization of stored NSC, or how/if NSCs are being translocated when phloem and xylem are assumed to be non-functional (Aloni et al., 1991; Améglio et al., 2001). Locally, the parenchyma cell tissue fraction of wood might provision for local NSC storage capacity, thus the relative contribution of parenchyma cells in wood might produce a trade-off between storage, water transport, and mechanical support (Hoch et al., 2003; Morris et al., 2015). Therefore, NSC requirements also have to be evaluated in terms of the storage size limits in order to quantify the local availability of NSC surrounding the bud. Insufficient NSC in tissues adjacent to a bud-whether they are transported there in spring or stored locally through the winter-can lead to delays in growth and development, decreased leaf area, and the induction of flower abortion (Lebon et al., 2008; Keller and Tarara, 2010; Tixier et al., 2017b).

\section{Spring NSC Remobilization and Transport Mechanisms}

Growing buds require a carbohydrate supply, mostly mono- or disaccharides (i.e., glucose, fructose, and sucrose) and sometimes sorbitol originating from starch hydrolysis in the parenchyma cells of xylem (Maurel et al., 2004; Keller, 2015). Bud break and growth could potentially utilize carbohydrates from local NSC reserves or NSC delivered via long-distance transport. At the onset of bud development in species such as peach, walnut, and grapevine, there is low starch variation near the bud, while there are increases in starch degrading enzyme activity and significant decreases of starch reserves at distant locations (Alves et al., 2007; Bonhomme et al., 2010; Rubio et al., 2014). Modeled NSC depletion from local maintenance respiration in walnut branches was much higher than observed carbohydrate depletion, suggesting a need for the replenishment of reserves from distal locations (Tixier et al., 2017a). Longdistance transport of labeled carbohydrates, grafting, girdling experiments, storage mobilization, and growth measurements also support the hypothesis that carbohydrates are transported from distant locations (Bates et al., 2002; Lacointe et al., 2004; Menora et al., 2015; Tixier et al., 2017b).

While long-distance transport during vegetative growth involving fully functional phloem and xylem is well-understood from the perspective of physics and biology, there is limited knowledge on long-distance transport mechanisms during winter and spring in the absence of transpiration (Münch, 1943; Angeles et al., 2004; Jensen et al., 2011). Given the observed range of carbohydrate concentration gradients found in the xylem, diffusion would not be capable of delivering enough carbohydrates to meet the demand of developing buds across more than a few centimeters. The amount of NSC required to sustain growth far exceeds local wood content, therefore the utilization of NSC stored over a few meters away may be required to sustain bud growth (Bates et al., 2002; Zufferey et al., 2012). Due to the prevailing assumption of phloem dormancy and the distinctive occurrence of sugar accumulation in its sap during bud break, xylem has been proposed as the primary path for long-distance NSC transport (Campbell and Strother, 1996). Yet, the role of root pressure and transpiration as driving forces for longdistant transport remain questionable. Without a concurrent leak, outflow, or backflow mechanism, it is unclear how root pressure could generate water movement. Transpiration is insufficient due to the minimal exposure of evaporative surface area in developing buds, especially at early stages (Tixier et al., 2017a).

Based on experimental observations and modeling, a novel mechanism for the maintenance of spring carbohydrate translocation in woody perennials has been proposed. In the absence of transpiration and prior to leaves' photosynthetic independence, phloem Münch flow would act as a pump to generate water flux in xylem allowing for the transport and mobilization of sugars from distant locations (Tixier et al., $2017 b)$. The accumulation of sugars in xylem sap in response to low temperatures may take part in the transport of NSC, especially when considering thermal gradients at the whole plant scale in spring when roots are colder than the canopy (Zwieniecki et al., 2015). Phloem transport capacity has been reported to be blocked during winter however it has also been suggested that a thin layer of phloem near the cambium remains active (Aloni et al., 1991). Other research suggests that phloem sieve tubes can remain active at temperatures below $-10^{\circ} \mathrm{C}$ (Fisher, 1983). Because analyzing functional phloem is technically challenging, our current knowledge relies upon only a few classical studies, which are now being challenged and complemented by advances in molecular biology and with the popular use of isotopes (Knoblauch and van Bel, 1998; Tarkowski and Van den Ende, 2015; Corot et al., 2017).

Whole tree level NSC management is highly responsive to temporal and spatial temperature gradients. Seasonal shifts in the average temperature of the soil and atmosphere are wellcorrelated with changes in the direction of carbohydrate flux through woody plants (Zwieniecki et al., 2015). When the soil is warmer than the atmosphere (fall and early winter) NSC accumulates in the roots, while when the atmosphere is warmer than the soil (spring and early summer) there is a shift of carbohydrates to the above ground biomass. Similar trends were observed on shorter time scales, indicating that carbohydrate redistribution might be influenced by gradients of temperatures across the architecture of the whole plant (roots to shoots) (Sperling et al., 2017).

\section{CONCLUSIONS AND FUTURE DIRECTIONS}

We argue that further progress in our understanding of dormancy hinges on applying new holistic multidisciplinary approaches integrating bud level genetic control with whole plant physiology to provide the foundations necessary for the 
development of robust predictive models. In the context of climate change it is crucial to understand the mechanisms of winter biology to better inform how projected increases in winter temperatures will affect the carbon budget, transport, and allocation which controls timing and success of growth resumption (Figure 2). In spring, NSCs need to be available at the right locations and time for a successful and synchronized bud break. This critical step for the fitness of perennial plants in natural and agricultural ecosystems affects the reproductive success and performance throughout the growing season.

\section{REFERENCES}

Aloni, R., Raviv, A., and Peterson, C. (1991). The role of auxin in the removal of dormancy callose and resumption of phloem activity. Can. J. Bot. 69, 1825-1832. doi: 10.1139/b91-232

Alves, G., Decourteix, M., Fleurat-Lessard, P., Sakr, S., Bonhomme, M., Améglio, T., et al. (2007). Spatial activity and expression of plasma membrane $\mathrm{H}+$-ATPase in stem xylem of walnut during dormancy and growth resumption. Tree Physiol. 27, 1471-1480. doi: 10.1093/treephys/ 27.10.1471

Amasino, R. (2010). Seasonal and developmental timing of flowering. Plant J. 61, 1001-1013. doi: 10.1111/j.1365-313X.2010.04148.x

Améglio, T., Bodet, C., Lacointe, A., and Cochard, H. (2002). Winter embolism, mechanisms of xylem hydraulic conductivity recovery and springtime growth patterns in walnut and peach trees. Tree Physiol. 22, 1211-1220. doi: 10.1093/treephys/22.17.1211

Améglio, T., Decourteix, M., Alves, G., Valentin, V., Sakr, S., Julien, J. L., et al. (2004). Temperature effects on xylem sap osmolarity in walnut trees: evidence for a vitalistic model of winter embolism repair. Tree Physiol. 24, 785-793. doi: 10.1093/treephys/24.7.785

Améglio, T., Ewers, F. W., Cochard, H., Martignac, M., Vandame, M., Bodet, C., et al. (2001). Winter stem xylem pressure in walnut trees: effects of carbohydrates, cooling and freezing. Tree Physiol. 21, 387-394. doi: 10.1093/treephys/21.6.387

Angeles, G., Bond, B., Boyer, J. S., Brooks, J. R., Burns, M. J., CavenderBares, J., et al. (2004). The cohesion-tension theory. N. Phytol. 163, 451-452. doi: 10.1111/j.1469-8137.2004.01142.x

Aslamarz, A. A., Vahdatia, K., Rahemi, M., and Hassani, D. (2010). Evaluation of chilling-heat requirements of some Persian walnut cultivars. Acta Hortic. 861, 317-320. doi: 10.17660/ActaHortic.2010.861.43

Atkin, O. K., and Tjoelker, M. G. (2003). Thermal acclimation and the dynamic response of plant respiration to temperature. Trends Plant Sci. 8, 343-351. doi: 10.1016/S1360-1385(03)00136-5

Bansal, S., and Germino, M. J. (2008). Carbon balance of conifer seedlings at timberline: relative changes in uptake, storage, and utilization. Oecologia 158, 217-227. doi: 10.1007/s00442-008-1145-4

Bansal, S., and Germino, M. J. (2010). Unique responses of respiration, growth, and non-structural carbohydrate storage in sink tissue of conifer seedlings to an elevation gradient at timberline. Environ. Exp. Bot. 69, 313-319. doi: 10.1016/j.envexpbot.2010.05.002

Barbaroux, C., and Bréda, N. (2002). Contrasting distribution and seasonal dynamics of carbohydrate reserves in stem wood of adult ring-porous sessile oak and diffuse-porous beech trees. Tree Physiol. 22, 1201-1210. doi: 10.1093/treephys/22.17.1201

Barros, P. M., Gonçalves, N., Saibo, N. J., and Oliveira, M. M. (2012). Functional characterization of two almond C-repeat-binding factors involved in cold response. Tree Physiol. 32, 1113-1128. doi: 10.1093/treephys/tps067

Bates, T. R., Dunst, R. M., and Joy, P. (2002). Seasonal dry matter, starch, and nutrient distribution in "Concord" grapevine roots. HortScience 37, 313-316. doi: 10.21273/HORTSCI.37.2.313

\section{AUTHOR CONTRIBUTIONS}

AT, GG, and MZ conceptualized the topic addressed in the manuscript. AT, GG, JG, JO, and MZ contributed to the writing of the manuscript.

\section{ACKNOWLEDGMENTS}

This work was supported by the California Pistachio Research Board, the Almond Board of California, and the California Walnut Board.

Beauvieux, R., Wenden, B., and Dirlewanger, E. (2018). Bud dormancy in perennial fruit tree species : a pivotal role for oxidative cues. Front. Plant Sci. 9:657. doi: 10.3389/fpls.2018.00657

Blanke, M. M., and Leyhe, A. (1989). Carbon economy of the grape inflorescence 1. Carbon economy in flower buds of grape. Viticul. Enol. Sci. 44, 33-36.

Bohlenius, H., Böhlenius, H., Huang, T., Charbonnel-Campaa, L., Brunner, A. M., Jansson, S., et al. (2006). CO/FT regulatory module controls timing of flowering and seasonal growth cessation in trees. Science 11, 1040-1043. doi: $10.1126 /$ science. 1126038

Bolouri Moghaddam M. R., and Van den Ende, W. (2013). Sugars, the clock and transition to flowering. Front. Plant Sci. 4:22. doi: 10.3389/fpls.2013.00022

Bonhomme, M., Peuch, M., Améglio, T., Rageau, R., Guilliot, A., Decourteix, M., et al. (2010). Carbohydrate uptake from xylem vessels and its distribution among stem tissues and buds in walnut (Juglans regia L.). Tree Physiol. 30, 89-102. doi: 10.1093/treephys/tpp103

Bonhomme, M., Rageau, R., Lacointe, A., and Gendraud, M. (2005). Influences of cold deprivation during dormancy on carbohydrate contents of vegetative and floral primordia and nearby structures of peach buds (Prunus persica L. Batch). Sci Horticul. 105, 223-240. doi: 10.1016/j.scienta.2005.01.015

Campbell, J. A., Strother, S. (1996). Seasonal variation in $\mathrm{pH}$, carbohydrate and nitrogen of xylem exudation of Vitis vinifera. Aust. J. Plant Physiol. 23, 115-118. doi: 10.1071/PP9960115

Campoy, J. A., Ruiz, D., and Egea, J. (2011). Dormancy in temperate fruit trees in a global warming context: a review. Sci. Hortic. 130, 357-372. doi: 10.1016/j.scienta.2011.07.011

Charrier, G., Lacointe, A., and Améglio, T. (2018). Dynamic modeling of carbon metabolism during the dormant period accurately predicts the changes in frost hardiness in walnut trees Juglans regia L. Front. Plant Sci. 9:1746. doi: 10.3389/fpls.2018.01746

Charrier, G., Ngao, J., Saudreau, M., and Améglio, T. (2015). Effects of environmental factors and management practices on microclimate, winter physiology, and frost resistance in trees. Front. Plant Sci. 6:259. doi: 10.3389/fpls.2015.00259

Cleland, E. E., Chuine, I., Menzel, A., Mooney, H. A., and Schwartz, M. D. (2007). Shifting plant phenology in response to global change. Trends Ecol Evol. 22, 357-365. doi: 10.1016/j.tree.2007.04.003

Corot, A., Roman, H., Douillet, O., Autret, H., Perez-Garcia, M. D., Citerne, S., et al. (2017). Cytokinins and abscisic acid act antagonistically in the regulation of the bud outgrowth pattern by light intensity. Front. Plant Sci. 8:1724. doi: 10.3389/fpls.2017.01724

Da Silva, D., Qin, L., Debuse, C., and Dejong, T. M. (2014). Measuring and modelling seasonal patterns of carbohydrate storage and mobilization in the trunks and root crowns of peach trees. Ann. Bot. 114, 643-652. doi: $10.1093 / \mathrm{aob} / \mathrm{mcu} 033$

Decourteix, M., Alves, G., Bonhomme, M., Peuch, M., Ben Baaziz K., Brunel, N., et al. (2008). Sucrose (JrSUT1) and hexose (JrHT1 and JrHT2) transporters in walnut xylem parenchyma cells : their potential role in early events of growth resumption. Tree Physiol. 28, 215-224. doi: 10.1093/treephys/28.2.215

DeJong, T. M., Da Silva, D., Vos, J., and Escobar-Gutiérrez, A. J. (2011). Using functional-structural plant models to study, understand and 
integrate plant development and ecophysiology. Ann. Bot. 108, 987-989. doi: $10.1093 / \mathrm{aob} / \mathrm{mcr} 257$

Díaz-Riquelme, J., Grimplet, J., Martínez-Zapater, J. M., and Carmona, M. J. (2012). Transcriptome variation along bud development in grapevine (Vitis vinifera L.). BMC Plant Biol. 12:181. doi: 10.1186/1471-2229-12-181

Fennell, A. Y., Schlauch, K. A., Gouthu, S., Deluc, L. G., Khadka, V., Sreekantan, L., et al. (2015). Short day transcriptomic programming during induction of dormancy in grapevine. Front. Plant Sci. 6:834. doi: 10.3389/fpls.2015.00834

Field, C. B., Barros, V. R., Dokken, D. J., Mach, K. J., Mastrandrea, M. D., Bilir, T. E., et al. (2014). Climate change 2014, impacts, adaptation, and vulnerability. Summaries, Frequently Asked Questions, and Cross-Chapter Boxes. A contribution of Working Group II to the Fifth Assessment Report of the Intergovernmental Panel on Climate Change (Geneva).

Fisher, D. B. (1983). Year-round collection of willow sieve-tube exudate. Planta 159, 529-533. doi: 10.1007/BF00409142

Ford, K. R., Harrington, C. A., Bansal, S., Gould, P. J., and St Clair, J. B. (2016). Will changes in phenology track climate change? A study of growth initiation timing in coast Douglas-fir. Global Change Biol. 2:3712-3723. doi: 10.1111/gcb. 13328

Gibon, Y., Bläsing, O. E., Palacios-Rojas, N., Pankovic, D., Hendriks, J. H., Fisahn, J., et al. (2004). Adjustment of diurnal starch turnover to short days: Depletion of sugar during the night leads to a temporary inhibition of carbohydrate utilization, accumulation of sugars and post-translational activation of ADPglucose pyrophosphorylase in the following light period. Plant J. 39, 847-862. doi: 10.1111/j.1365-313X.2004.02173.x

Guo, L., Dai, J., Wang, M., Xu, J., and Luedeling, E. (2015). Responses of spring phenology in temperate zone trees to climate warming: a case study of apricot flowering in China. Agric Forest Meteorol. 201, 1-7. doi: 10.1016/j.agrformet.2014.10.016

Hartmann, H., and Trumbore, S. (2016). Understanding the roles of nonstructural carbohydrates in forest trees - from what we can measure to what we want to know. N. Phytol. 211, 386-403. doi: 10.1111/nph.13955

Heide, O. M. (2008). Interaction of photoperiod and temperature in the control of growth and dormancy of Prunus species. Sci. Hortic. 115, 309-314. doi: 10.1016/j.scienta.2007.10.005

Heide, O. M. (2011). Temperature rather than photoperiod controls growth cessation and dormancy in Sorbus species. J. Exp. Bot. 62, 5397-5404. doi: $10.1093 / \mathrm{jxb} / \mathrm{err} 213$

Hoch, G., Richter, A., and Korner, C. (2003). Non-structural carbon compounds in temperate forest trees. Plant Cell Environ. 26, 1067-1081. doi: 10.1046/j.0016-8025.2003.01032.x

Ibañez, C., Ramos, A., Acebo, P., Contreras, A., Casado, R., Allona, I., et al. (2008). Overall alteration of circadian clock gene expression in the chestnut cold response. PLoS ONE 3:3567. doi: 10.1371/journal.pone.0003567

Jae-Hoon, J., Mirela, D., Cornelia, K., Surojit, B., Daphne, E., Mingjun, G., et al. (2016). Phytochromes function as thermosensors in Arabidopsis. Science 354, :886-889. doi: 10.1126/science.aaf6005

Jensen, K. H., Lee, J., Bohr, T., Bruus, H., Holbrook, N. M., and Zwieniecki, M. A. (2011). Optimality of the Münch mechanism for translocation of sugars in plants. J. R. Soc. Interface 8, 1155-1165. doi: 10.1098/rsif.2010.0578

Kaufmann, H., and Blanke, M. (2017). Performance of three numerical models to assess winter chill for fruit trees-a case study using cherry as model crop in Germany. Region. Environ. Change 17, 715-723. doi: 10.1007/s10113-016-1064-6

Keller, M. (2015). The Science of Grapevines: Phenology and Growth Cycle. Burlington, MA: Academic Press.

Keller, M., and Tarara, J. M. (2010). Warm spring temperatures induce persistent season-long changes in shoot development in grapevines. Ann. Bot. 106, 131-141. doi: 10.1093/aob/mcq091

Kim, S. A., Ahn, S. Y., and Yun, H. K. (2017). Transcriptomic changes in dormant buds of two grapevine cultivars following exposure to freezing temperature. Horticul. Environ. Biotechnol. 58, 152-161. doi: 10.1007/s13580-0170147-8

Knoblauch, M., van Bel A. J. E. (1998). Sieve tubes in action. Plant Cell 10, 35-50. doi: $10.1105 /$ tpc. 10.1 .35

Lacointe, A., Deleens, E., Ameglio, T., Saint-Joanis, B., Lelarge, C., Vandame, M., et al. (2004). Testing the branch autonomy theory: A $13 \mathrm{C} / 14 \mathrm{C}$ double-labelling experiment on differentially shaded branches.
Plant Cell Environ. 27, 1159-1168. doi: 10.1111/j.1365-3040.2004.0 1221.x

Lebon, G., Wojnarowiez, G., Holzapfel, B., Fontaine, F., Vaillant-Gaveau, N., and Clément, C. (2008). Sugars and flowering in the grapevine (Vitis vinifera L.). J. Exp. Bot. 59, 2565-2578. doi: 10.1093/jxb/ern135

Legris, M., Klose, C., Burgie, E. S., Rojas, C. C., Neme, M., Hiltbrunner, A., et al. (2016). Phytochrome B integrates light and temperature signals in Arabidopsis. Science. 354, 897-900. doi: 10.1126/science.aaf5656

Lens, F., Tixier, A., Cochard, H., Sperry, J. S., Jansen, S., and Herbette, S. (2012). Embolism resistance as a key mechanism to understand adative plant strategies. Curr. Opin. Plant Biol. 16, 1-6. doi: 10.1016/j.pbi.2013.02.005

Leyhe, A., and Blanke, M. M. (1989). NKohlenstoff-Haushalt der infroreszenz der rebe 2. Co2- Gaswechsel der Blutenstande und Winbeere. Viticul. Enol. Sci. $44,147-150$.

Loescher, W. H., Mccamant, T., and Keller, J. D. (1990). Carbohydrate reserves, translocation, and storage in woody plant roots. HortScience 25, 274-281.

Londo, J. P., and Johnson, L. M. (2014). Variation in the chilling requirement and budburst rate of wild Vitis species. Environ. Exp. Bot. 106, 138-147. doi: 10.1016/j.envexpbot.2013.12.012

Luedeling, E., and Brown, P. H. (2011). A global analysis of the comparability of winter chill models for fruit and nut trees. Int. J. Biometeorol. 55, 411-421. doi: 10.1007/s00484-010-0352-y

Luedeling, E., Guo, L., Dai, J., Leslie, C., and Blanke, M. M. (2013). Differential responses of trees to temperature variation during the chilling and forcing phases. Agricul. Forest Meteorol. 181, 33-42. doi: 10.1016/j.agrformet.2013.06.018

Mathiason, K., He, D., Grimplet, J., Venkateswari, J., Galbraith, D. W., Or, E., et al. (2009). Transcript profiling in Vitis riparia during chilling requirement fulfillment reveals coordination of gene expression patterns with optimized bud break. Funct. Integr. Genom. 9, 81-96. doi: 10.1007/s10142-008-0090-y

Maurel, K., Leite, G. B., Bonhomme, M., Guilliot, A., Rageau, R., Pétel, G., et al. (2004). Trophic control of bud break in peach (Prunus persica) trees: a possible role of hexoses. Tree Physiol. 24, 579-588. doi: 10.1093/treephys/24.5.579

Maurya, J. P., and Bhalerao, R. P. (2017). Photoperiod- and temperature-mediated control of growth cessation and dormancy in trees: a molecular perspective. Ann. Bot. 120, 351-360. doi: 10.1093/aob/mcx061

Menora, D. N., Joshi, V., Kumar, V., Vijaya, D., Kanti Debn, M., Pattanashe, S., et al. (2015). Influence of rootstock on bud break, period of anthesis, fruit set, fruit ripening, heat unit requirement and berry yield of commercial grape varieties. Int J Plant Breed Genetics 9, 126-135. doi: 10.3923/ijpbg.2015.126.135

Morris, H., Plavcová, L., Cvecko, P., Fichtler, E., Gillingham, M. A., MartínezCabrera, H. I., et al. (2015). A global analysis of parenchyma tissue fractions in secondary xylem of seed plants. N. Phytol. 209, 1553-1565. doi: 10.1111/nph.13737

Mosedale, J. R., Abernethy, K. E., Smart, R. E., Wilson, R. J., and Maclean, I. M. (2016). Climate change impacts and adaptive strategies: lessons from the grapevine. Glob. Chang. Biol. 22, 3814-3828. doi: 10.1111/gcb.13406

Münch, E. (1943). Durchlassigkeit der siebrohren fur druckstro mungen. Flora 136, 223-262. doi: 10.1016/S0367-1615(17)31221-1

Palacio, S., Hoch, G., Sala, A., Körner, C., and Millard, P. (2014). Does carbon storage limit tree growth? N. Phytol. 201, 1096-1100. doi: 10.1111/nph.12602

Parada, F., Noriega, X., Dantas, D., Bressan-Smith, R., and Pérez, F. J. (2016). Differences in respiration between dormant and non-dormant buds suggest the involvement of $\mathrm{ABA}$ in the development of endodormancy in grapevines. $J$. Plant Physiol. 201, 71-78. doi: 10.1016/j.jplph.2016.07.007

Pellegrino, A., Clingeleffer, P., Cooley, N., and Walker, R. (2014). Management practices impact vine carbohydrate status to a greater extent than vine productivity. Front. Plant Sci. 5:283. doi: 10.3389/fpls.2014.00283

Pérez, F. J., Orme-o, N. J., Reynaert, B., and Rubio, S. (2008). Use of the dynamic model for the assessment of winter chilling in a temperate and a subtropical climatic zone of Chile. Chil. J. Agric. Res. 68, 198-206. doi: 10.4067/S0718-58392008000200010

Richardson, A. D., Carbone, M. S., Keenan, T. F., Czimczik, C. I., Hollinger, D. Y., Murakami, P., et al. (2013). Seasonal dynamics and age of stemwood nonstructural carbohydrates in temperate forest trees. N. Phytol. 197, 850-861. doi: $10.1111 / \mathrm{nph} .12042$

Rinne, P., Tuominen, H., and Junttila, O. (1994). Seasonal changes in bud dormancy in relation to bud morphology, water and starch content, and 
abscisic acid concentration in adult trees of Betula pubescens. Tree Physiol. 14, 549-561. doi: 10.1093/treephys/14.6.549

Rodriguez,-A. J., Sherman, W. B., Scorza, R., Wisniewski, M., and Okie, W. R. (1994). "Evergreen" peach, its inheritance and dormant behavior. J. Am. Soc. Horticul. Sci. 119, 789-792. doi: 10.21273/JASHS.119.4.789

Rohde, A., and Bhalerao, R. P. (2007). Plant dormancy in the perennial context. Trends Plant Sci. 12, 217-223. doi: 10.1016/j.tplants.2007.03.012

Rosas, T., Galiano, L., Ogaya, R., Peñuelas, J. J., and Martínez-Vilalta, J. (2013). Dynamics of non-structural carbohydrates in three Mediterranean woody species following long-term experimental drought. Front. Plant Sci. 4:400. doi: $10.3389 /$ fpls.2013.00400

Rubio, S., Donoso, A., and Pérez, F. J. (2014). The dormancy-breaking stimuli 'chilling, hypoxia and cyanamide exposure' up-regulate the expression of $\alpha$-amylase genes in grapevine buds. J. Plant Physiol. 171, 373-381. doi: 10.1016/j.jplph.2013.11.009

Ruttink, T., Arend, M., Morreel, K., Storme, V., Rombauts, S., Fromm, J., et al. (2007). A molecular timetable for apical bud formation and dormancy induction in poplar. Plant Cell Online 19, 2370-2390. doi: 10.1105/tpc.107.052811

Sánchez-Pérez, R., Del Cueto, J., Dicenta, F., and Martínez-Gómez, P. (2014). Recent advancements to study flowering time in almond and other Prunus species. Front. Plant Sci. 5:334. doi: 10.3389/fpls.2014.00334

Sanz-Pérez, V., Castro-Díez, P., and Valladares, F. (2009). Differential and interactive effects of temperature and photoperiod on budburst and carbon reserves in two co-occurring Mediterranean oaks. Plant Biol. 11, 142-151. doi: 10.1111/j.1438-8677.2008.00119.x

Schrader, J., Moyle, R., Bhalerao, R., Hertzberg, M., Lundeberg, J., Nilsson, P., et al. (2004). Cambial meristem dormancy in trees involves extensive remodelling of the transcriptome. Plant J. 40, 173-187. doi: 10.1111/j.1365-313X.2004. 02199.x

Singh, R. K., Svystun, T., AlDahmash, B., Jönsson, A. M., and Bhalerao, R. P. (2017). Photoperiod- and temperature-mediated control of phenology in trees - a molecular perspective. N. Phytol. 213, 511-524. doi: 10.1111/np h. 14346

Sperling, O., Earles, J. M., Secchi, F., Godfrey, J., and Zwieniecki, M. A. (2015). Frost induces respiration and accelerates carbon depletion in trees. PLOS ONE 10:e0144124. doi: 10.1371/journal.pone.0144124

Sperling, O., Silva, L. C. R., Tixier, A., Théroux-Rancourt, G., and Zwieniecki, M. A. (2017). Temperature gradients assist carbohydrate allocation within trees. Sci. Rep. 7, 3265-3275. doi: 10.1038/s41598-017-03608-w

Sudawan, B., Chang, C. S., Chao, H. F., Ku, M. S. B., Yen, Y. F. (2016). Hydrogen cyanamide breaks grapevine bud dormancy in the summer through transient activation of gene expression and accumulation of reactive oxygen and nitrogen species. BMC Plant Biol. 16:202. doi: 10.1186/s12870-0160889-y

Tarkowski, Ł. P., and Van den Ende, W. (2015). Cold tolerance triggered by soluble sugars: a multifaceted countermeasure. Front. Plant Sci. 6:203. doi: $10.3389 /$ fpls.2015.00203

Tixier, A., Orozco, J., Amico Roxas, A., Earles, J. M., and Zwieniecki, M. A. (2018). Diurnal variation in non-structural carbohydrate storage in trees: remobilization and vertical mixing. Plant Physiol. 178:00923.2018. doi: $10.1104 /$ pp. 18.00923

Tixier, A., Roxas, A. A., Godfrey, J., Saa, S., Lightle, D., Maillard, P., et al. (2017a). Role of bark color on stem temperature and carbohydrate management during dormancy break in persian walnut. J. Am. Soc. Horticul. Sci. 142, 454-463. doi: 10.21273/JASHS04216-17

Tixier, A., Sperling, O., Orozco, J., Lampinen, B., Amico Roxas, A., Saa, S., et al. (2017b). Spring bud growth depends on sugar delivery by xylem and water recirculation by phloem Münch flow in Juglans regia. Planta 246, 495-508. doi: 10.1007/s00425-017-2707-7

Vaillant-Gaveau, N., Maillard, P., Wojnarowiez, G., Gross, P., Clément, C., and Fontaine, F. (2011). Inflorescence of grapevine (Vitis vinifera L.): a high ability to distribute its own assimilates. J. Exp. Bot. 62, 4183-4190. doi: $10.1093 /$ jxb/err121

van der Schoot, C., and Rinne, P. L. (2011). Dormancy cycling at the shoot apical meristem: transitioning between self-organization and self-arrest. Plant Sci. 180, 120-131. doi: 10.1016/j.plantsci.2010. 08.009

Wigge, P. A. (2013). Ambient temperature signalling in plants. Curr. Opin. Plant Biol. 16, 661-666. doi: 10.1016/j.pbi.2013.08.004

Witt, W., and Sauter, J. J. (1994). Starch metabolism in poplar wood ray cells during spring mobilization and summer deposition. Physiol. Plant. 92, 9-16. doi: 10.1034/j.1399-3054.1994.920102.x

Yordanov, Y. S., Ma, C., Strauss, S. H., and Busov, V. B. (2014). EARLY BUD-BREAK 1 (EBB1) is a regulator of release from seasonal dormancy in poplar trees. Proc. Natl. Acad. Sci. U.S.A. 111, 10001-10006. doi: 10.1073/pnas.1405621111

Zheng, C., Halaly, T., Acheampong, A. K., Takebayashi, Y., Jikumaru, Y., Kamiya, Y., et al. (2015). Abscisic acid (ABA) regulates grape bud dormancy, and dormancy release stimuli may act through modification of ABA metabolism. J. Exp. Bot. 66, 1527-1542. doi: 10.1093/jxb/ eru519

Zufferey, V., Murisier, F., Vivin, P., Belcher, S., Lorenzini, F., Spring J. L., Viret, O. (2012). Carbohydrate reserves in grapevine (Vitis vinifera L. 'Chasselas'): the influence of the leaf to fruit ratio. Vitis 51, 103-110

Zwieniecki, M. A., Tixier, A., and Sperling, O. (2015). Temperature-assisted redistribution of carbohydrates in trees. Am. J. Bot. 102, 1216-1218. doi: 10.3732/ajb.1500218

Conflict of Interest Statement: The authors declare that the research was conducted in the absence of any commercial or financial relationships that could be construed as a potential conflict of interest.

Copyright (C) 2019 Tixier, Gambetta, Godfrey, Orozco and Zwieniecki. This is an open-access article distributed under the terms of the Creative Commons Attribution License (CC BY). The use, distribution or reproduction in other forums is permitted, provided the original author(s) and the copyright owner(s) are credited and that the original publication in this journal is cited, in accordance with accepted academic practice. No use, distribution or reproduction is permitted which does not comply with these terms. 